\title{
Effects of nicorandil on vascular and renal dysfunctions in adenine- induced nephropathy: Possible underlying mechanisms
}

\author{
Abdelaziz M. Hussein ${ }^{1}$, Mohamed Eldosoky ${ }^{1}$, Hala Abdel Malek², Mohamed Elshafey ${ }^{3}$, \\ Eman El Nashar ${ }^{4,5}$ and Gamal Dahab ${ }^{2}$ \\ ${ }^{1}$ Medical Physiology Department, Faculty of Medicine, Mansoura University, Mansoura, Egypt \\ ${ }^{2}$ Clinical Pharmacology Department, Faculty of Medicine, Mansoura University, Mansoura, Egypt \\ ${ }^{3}$ Anatomy Department, Faculty of Medicine, Mansoura University, Mansoura, Egypt \\ ${ }^{4}$ Department of Anatomy, College of Medicine, King Khalid University, Abha, KSA \\ ${ }^{5}$ Department of Histology and Cell biology, Faculty of Medicine, Benha University, Benha, Egypt
}

\begin{abstract}
Vascular dysfunctions in chronic kidney disease (CKD) include endothelial dysfunctions and vascular calcification (VC). In the present study, we examined the possible protective effect of nicorandil (potassium channel opener) on renal and vascular dysfunctions in a rat model of adenine-induced nephropathy and its underlying mechanisms. Thirty-four male Sprague-Dawley rats were randomly allocated into 3 groups: Control group, Adenine group (animals received high-adenine diet for 4 weeks), and Nicorandil group (animals received adenine for 4 weeks and nicorandil $1 \mathrm{mg} / \mathrm{kg}$ per oral for 4 weeks). The results showed significant reduction in the body weight, heart rate (HR), hemoglobin contents, serum $\mathrm{Ca}^{2+}$ and reduction in the expression of mRNA of endothelial nitric oxide synthase (eNOS) and nuclear factor erythroid related factor 2 (nrf2) genes in aortic tissues with significant increase in arterial blood pressure (ABP), serum creatinine, blood urea nitrogen (BUN), plasma renin activity (PRA), $\mathrm{K}^{+}$and phosphate $\left(\mathrm{PO}_{4}{ }^{3-}\right)$, urinary albumin excretion (UAE) and aortic VC in Adenine group compared to normal group $(p<0.05)$. On the other hand, coadminsitration of nicorandil caused significant improvement in the studied parameters compared to Adenine group $(p<0.05)$. We concluded that nicorandil has a potential protective effect against the vascular and renal impairment induced by adenine, which might be due to attenuation of vascular calcifications, activation of Nrf2 and eNOS genes in aortic tissues.
\end{abstract}

Key words: Nicorandil - Adenine - Vascular calcifications - Kidney - eNOS - Nrf2

\begin{abstract}
Abbreviations: $\mathrm{ABP}$, arterial blood pressure; $\mathrm{CKD}$, chronic kidney disease; $\mathrm{CV}$, cardiovascular; $\mathrm{eNOS}$, endothelial nitric oxide synthase; ESRD, end stage renal disease; Hb, hemoglobin; HR, heart rate; NO, nitric oxide; nrf2, nuclear factor erythroid related factor 2; PRA, plasma renin activity; RIA, radioimmune assay; UAE, urinary albumin excretion; VC, vascular calcifications.
\end{abstract}

\section{Introduction}

Chronic kidney disease (CKD) is a worldwide health problem that is increasing in both developed and developing countries (Levey et al. 2007). The disease is insidious over

Correspondence to: Abdel-Aziz M. Hussein, Physiology Department, Faculty of Medicine, Mansoura University, Mansoura, Egypt E-mail: zizomenna28@yahoo.com ; menhag@mans.edu.eg many years, and may result in end-stage renal disease (ESRD) that needs enhancement of kidney function by dialysis or transplantation, with poor patient outcomes (Chang et al. 2015), but till now the determinants of progression of CKD to ESRD are poorly understood (Diwan et al. 2018). One of the serious complications of CKD patients is the development of cardiovascular disease, which is considered the main cause of morbidity and mortality in these patients (López-Novoa 2012; Nguy et 
al. 2013). Cardiovascular mortality is 10-30 times higher in patients with CKD compared with age matched controls with normal kidney function (Sarnak et al. 2003) and accounts for approximately $50 \%$ of all deaths in patients on dialysis and in recipients of renal transplants (Nguy et al. 2012). Moreover, the majority of CKD patients die from cardiovascular (CV) events before developing end-stage renal disease (Sarnak et al. 2003). Also, the prevalence of hypertension is $87-90 \%$ patients with CKD patients (Levin 2003), but the details of interactions between the kidneys and the cardiovascular system remain unclear.

Adenine-induced nephropathy produces progressive CKD with cardiovascular changes, mimicking more closely the pathophysiology of human CKD (Lavi-Moshayoff et al. 2010). The mechanisms underlying renal dysfunctions in adenine-induced nephropathy include oxidative stress, inflammatory reaction, apoptosis and fibrosis (Askari et al. 2016; Diwan et al. 2018). The vascular dysfunctions in adenine-induced nephropathy that leads to development of hypertension might include endothelial dysfunctions and vascular calcifications (VC). VC are positively correlated with cardiovascular morbidity or mortality in patients with CKD and ESRD (Chang et al. 2017) and reported in early stages of CKD (Porter et al. 2007; Sigrest et al. 2007) and in young dialysis patients (Oh et al. 2002) and is considered a real challenge for management of ERSD patients (Franczyk-Skóra et al. 2013). The mechanisms underlying VC are complex in which oxidative stress play a major role (Yamada et al. 2012; Chang et al. 2017). Also, endothelial dysfunction in CKD leads to significant depletion of nitric oxide (NO) produced by endothelial NO synthase (eNOS) with elevation in vasoconstrictors such as endothelin (Peng et al. 2013; Ali et al. 2015). Nuclear factor-erythroid2-related factor 2 (Nrf2) is a transcription factor that regulates the expression of more than 200 antioxidant and cytoprotective genes (Vomund et al. 2017). Several studies demonstrated decrease in Nrf2 activity and the expression of its targets antioxidant genes in animal models of CKD (Aminzadeh et al. 2013; Soetikno et al. 2013; Trujillo et al. 2013). Therefore, we hypothesized that activation of $n r f 2$ genes could improve the renal and vascular dysfunctions in adenine-induced nephropathy.

Nicronadil, 2-[(pyridin-3-ylcarbonyl) amino-ethyl nitrate, is a clinically proven anti-anginal agent that causes vasodilatation by opening ATP-dependent $\mathrm{K}^{+}$channels and also releasing NO (Barbato 2005). Apart from the proven efficacy in treating $\mathrm{CKD}$, nicorandil is also beneficial in patients with ESRD undergoing hemodialysis, by reducing oxidative damage (Ishii et al. 2007). In addition to these protective effects, nicorandil has been recently reported to have benefit in experimental renal disease including in the renal injury induced by ischemia-reperfusion (Shimizu et al. 2011) and glomerulonephritis (Sudo et al. 2009). Nico- randil also significantly alleviated chronic renal injury of remnant kidney model of chronic renal injury by targeting podocytes and macrophages (Tamura et al. 2012), which indicates the potential protective effects of nicorandil on chronic renal failure and associated cardiovascular complication specially VC. Recently, Ravindran et al. (2017a) demonstrated that the cardioprotective effect of nicorandil against ischemia/reperfusion injury was abolished by VC, and Ravindran et al. (2017b) found that nicorandil ameliorates the oxidative stress and mitochondrial dysfunctions in brain tissues of murine model of VC. Therefore, we hypothesized that nicorandil could attenuate the renal and vascular dysfunctions by attacking VC and vascular antioxidant genes such as nrf2 and eNOS. So, the present study was conducted to investigate the possible protective effect of nicorandil on the vascular and renal dysfunctions in a rat model of adenine-induced CKD and its possible underlying mechanisms.

\section{Materials and Methods}

\section{Experimental animals}

Thirty-four male Sprague-Dawley rats weighing 180200 g (8-10 weeks old) were individually housed in standard cages at Department of Pharmacology, Mansoura Faculty of Medicine, maintained on a 12-h light-dark cycle and fed on standard diet and water ad libitum. All experimental procedures were conducted in accordance with the Guidelines for the Care and Use of Laboratory Animals by National Academy of Sciences (USA) and approved by our local committee of institutional review board (IRB).

\section{Study design}

Animals were randomly allocated into 3 main groups:

1. Control group $(n=10)$ : rats received normal standard chow with $0.5 \mathrm{ml}$ saline i.p. daily for 4 weeks

2. Adenine group $(n=12)$ : rats received high-adenine diet and $0.5 \mathrm{ml}$ saline i.p. daily for 4 weeks

3. Nicorandil group $(n=12)$ : rats received high adenine diet and nicorandil $1 \mathrm{mg} / \mathrm{kg}$ dissolved in $0.5 \mathrm{ml}$ saline for 4 weeks (Sudo et al. 2008).

\section{Induction of tubulointerstitial nephropathy by high adenine diet rat model}

One week before the start of the experiment, rats from all studied groups fed on normal standard chow. Then, rats of Control group continued on the same normal chow and rats of Adenine and Nicorandil groups fed on high adenine diet 


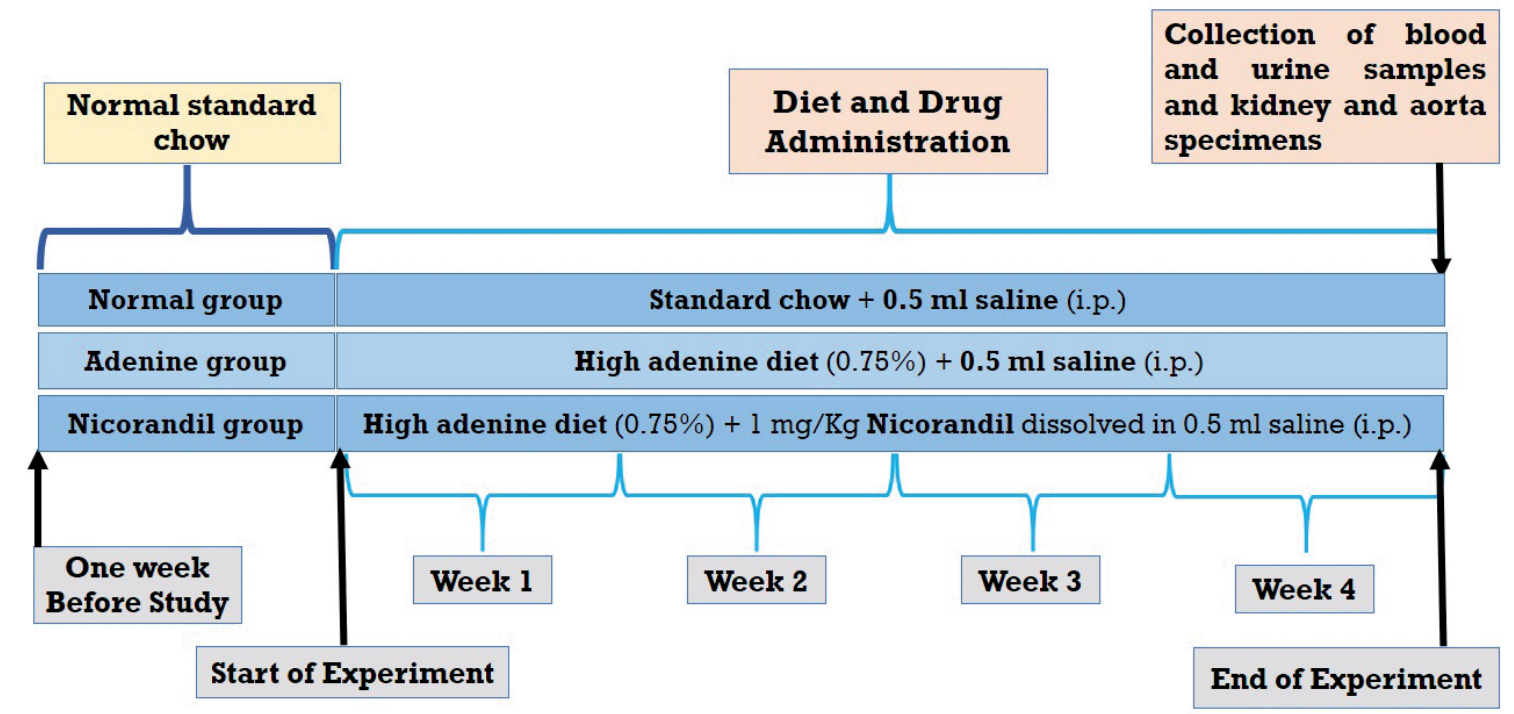

Figure 1. Scheme of experimental study design.

for 4 weeks (see Fig. 1). Table 1 shows the composition of the normal standard chow and high adenine diet.

\section{Measurement of body mass, heart rate and mean arterial blood pressure}

By the end of the experiment, the body mass of rats in grams was measured. Heart rate and mean arterial blood pressure were measured by non-invasive indirect rat tail pressure meter (Panlab Harvard apparatus, LE5001, Spain LE 5001) at Department of Medical Physiology, Mansoura Faculty of Medicine. The rats were allowed to adapt the method 3 days before initiation of the measurement. Unanaethetized rat was placed in a restrainer of appropriate size and its tail was placed inside a tail cuff and was allowed to equilibrate for few minutes till its heart rate is settled. Three consecutive reading was obtained for each rat and the mean of these readings was calculated.

Collection of blood and urine samples and harvesting kidney and aorta specimens

The rats were placed in metabolic cages for collection of $24 \mathrm{~h}$ and blood samples were obtained from the ophthalmic venous plexus using a fine-walled Pasteur pipette under halothane anesthesia (rats were anesthetized for one minute by placing it in a glass container with piece of cotton soaked with halothane). The blood sample was then centrifuged and the serum was stored at $-20^{\circ} \mathrm{C}$ until biochemical analysis.

By the end of the experiment, rats were sacrificed using high dose of sodium thiopental $(120 \mathrm{mg} / \mathrm{kg}$ i.p. $)$, then the thorax and abdomen were rapidly opened and kidneys were harvested, bisected and fixed into formalin $10 \%$ for histopathological study and the thoracic and abdominal aorta was dissected and divided into 2 parts; one part was fixed in $10 \%$ neutral phosphate-buffered saline (PBS) with $4 \%$ paraformaldehyde over-night for histological study and the second one was rapidly frozen and stored at liquid nitrogen $-170^{\circ} \mathrm{C}$ for molecular study.

\section{Assay of serum and urinary biomarkers}

Serum creatinine and electrolytes $\left(\mathrm{Na}^{+}, \mathrm{K}^{+}, \mathrm{PO}_{4}{ }^{-}, \mathrm{Ca}^{2+}\right)$ and hemoglobin contents, were measured by specific kits according to manufacturer instructions. Kits were purchased from Diamond Diagnostics, Egypt (serum creatinine), Stanbio Lab., Texas, USA (urea and uric acid), and Biomed DiagnosticsEGY-Chem., Egypt $\left(\mathrm{Na}^{+}, \mathrm{PO}_{4}^{-}, \mathrm{Ca}^{2+}\right)$. Assay of urinary albumin excretion was achieved using specific kits (Fortress Diagnostics Limited Unit 2C Antrim Technology Park, Antrim

Table 1. Composition of standard chow and high adenine diet (for each $100 \mathrm{~g}$ pellet)

\begin{tabular}{cc}
\hline Standard Chow & High adenine diet \\
\hline $0.92 \%$ phosphorus & $0.92 \%$ phosphorus \\
$1.06 \%$ calcium & $1.06 \%$ calcium \\
$2.5 \%$ protein (casein) & $2.5 \%$ protein (casein) \\
$4.7 \%$ fats & $4.7 \%$ fats \\
$5 \%$ cellulose & $5 \%$ cellulose \\
$75.3 \%$ sugars & $74.6 \%$ sugars \\
& $0.75 \%$ adenine \\
\hline
\end{tabular}


BT41 1QS, United Kingdom). Plasma renin activity (PRA) was determined by RIA kit and expressed as $\mathrm{ng} \mathrm{AngI} / \mathrm{ml} / \mathrm{h}$.

\section{Histopathological examination of kidney}

Kidney specimens were dehydrated in alcohol series, cleared in toluene and embedded in paraffin. The paraffin-embedded kidney sections stained with hematoxylin and eosin (H\&E) and examined under a photomicroscope (Nikon Eclipse, Japan). H\&E stained sections were examined for glomerular lesions (glomerulosclerosis, segmental collapse, proliferation, and mesangial expansion) and tubulointerstitial lesions (leukocyte infiltration, fibrosis, tubular dilatation, or atrophy). The degree of kidney damage was scored as follows: 0 , normal; grade $1,<10 \%$; grade $2,10-24 \%$; grade $3,25-49 \%$; grade 4 , 50-74\%; and grade 5, 75-100\% (Nicholas et al. 2012).

\section{Histological study of aorta}

About 2-3 mm rings of the aorta were embedded upright in paraffin blocks, so that every aortic section comprises on average eight to nine cross-sections (minimum six) at different sites along the vessel. Sections $(3-4 \mu \mathrm{m})$ some slides were stained with H\&E stain. Other slides were stained for calcification with Von Kossa's method. In brief, the sections were first deparaffinized and then re-hydrated to distilled water. Then they were placed in $1 \%$ silver nitrated and exposed to ultraviolet light (20 min). Afterwards they were placed in 5\% sodium thiosulfate ( $2 \mathrm{~min}$ ) and finally counterstained with nuclear Fast Red (5 min). Areas of calcification appeared as dark brown regions in the medial wall of the aortas.

Measurement of endothelial nitric oxide synthase (eNOS) and Nrf2 in aortic tissues RNA extraction and cDNA synthesis for aortic tissues

Total RNA from aortic tissues was isolated by the disruption of 50-100 mg tissues in $1 \mathrm{ml}$ of Trizol, according to the manufacturer's instructions (Invitrogen Corporation, Grand Island, New York, USA). RNA was quantified spectrophotometrically, and its quality was determined by agarose gel electrophoresis and ethidium bromide staining. Only samples that were not degraded and showed clear $18 \mathrm{~S}$ and $28 \mathrm{~S}$ bands under ultraviolet light were used for real time RT-PCR. Reverse transcription was done using $1 \mu \mathrm{g}$ total RNA and a cDNA kit (high-capacity cDNA archive kit, Applied Biosystems, USA).

\section{Primer and probe sequences of tested genes}

The primer sequences for the tested gene, $e N O S$ were as follows: forward, $5=$ GGACCCAAGTTTCCTCGAGTAA-3=; reverse, $5=$ GGATCCCAAGCAGCGTCTT $-3=$; probe, 5=FAM -
CAGCAT CACCTACGATACCCTCAGTGCA-TAMRA-3, nrf2: forward, 5'-GCTATTTTCCATTCCCGAGTTAC-3'; reverse, 5'-ATTGCTGTCCATCTCTGTCAG-3'; and GAPDH: forward, 5'-TATCGGACGCCTGGTTAC-3'; reverse, 5'- CTGTGCCGTTGAACTTGC-3-' (Hussein et al. 2016).

\section{Real-time PCR reaction}

The reaction was performed in a total volume of $50 \mu$, which comprised $25 \mu$ l of a mixture of 1 _ TaqMan ${ }^{\bullet}$ Universal PCR with $25 \mu$ lof 20_ TaqMan ${ }^{\circ}$ Gene Expression Assay Mix, plus $22.5 \mu \mathrm{l}$ of cDNA diluted in RNase-free water. The cycling parameters were as follows: initial denaturation at $95^{\circ} \mathrm{C}$ for $10 \mathrm{~min}$, followed by 40 cycles of denaturation $95^{\circ} \mathrm{C}$ for $15 \mathrm{~s}$, annealing at $60^{\circ} \mathrm{C}$ for $1 \mathrm{~min}$, and extension at $72^{\circ} \mathrm{C}$ for $1 \mathrm{~min}$. Data analysis was carried out using ABI prism 7000 by the equation $2{ }^{\mathrm{d}} C T$ (Livak and Schmittgen 2001).

\section{Statistical analysis}

SPSS (Statistical package for social science) program version 17.0 was used for doing statistical analysis. Data were presented in the form of mean \pm standard deviation (SD). One-way ANOVA (analysis of variance) test with Tukey post hoc test were used to find the statistical significance between studied groups. $p \leq 0.05$ is considered significant.

\section{Results}

\section{Animal survival}

No animals died in Control group, while in Adenine group, 4 animals were died and in Nicorandil group 2 animals were died.

Effects of nicorandil on final body weight, heart rate, mean $A B P, H b$ in adenine-induced nephropathy

Adenine feeding $(0.75 \%, \mathrm{w} / \mathrm{w})$ for 4 weeks caused a significant reduction in the body weight, $\mathrm{Hb}$ and $\mathrm{HR}$ with significant increase in mean ABP compared to Control group $(p<0.001)$. On the other hand, co-administration of nicorandil with adenine attenuated these effects as it significantly increased body weight, $\mathrm{HR}$ and $\mathrm{Hb}$ with significantly decreased the mean ABP when compared to Adenine group $(p<0.001)$ (Table 2).

Effects of nicorandil on serum creatinine, serum electrolytes $\left(\mathrm{Na}^{+}, \mathrm{K}^{+}, \mathrm{PO}_{4}^{-}, \mathrm{Ca}^{2+}\right)$, urinary protein excretion and $\mathrm{PRA}$ in adenine-induced nephropathy

Adenine feeding for 4 weeks caused significant elevation in serum urea, creatinine, $\mathrm{Na}^{+}, \mathrm{K}^{+}, \mathrm{PO}_{4}^{-}, \mathrm{PRA}$ and urinary 
Table 2. Effects of treatment with nicorandil on final body weight, heart rate, mean arterial blood pressure $(\mathrm{ABP})$ and hemoglobin level $(\mathrm{Hb})$

\begin{tabular}{lccc}
\hline & $\begin{array}{c}\text { Control group } \\
(n=10)\end{array}$ & $\begin{array}{c}\text { Adenine group } \\
(n=8)\end{array}$ & $\begin{array}{c}\text { Nicorandil group } \\
(n=10)\end{array}$ \\
\hline Final body weight $(\mathrm{g})$ & $269.69 \pm 10.73$ & $218.4 \pm 8.07^{\mathrm{a}}$ & $231.54 \pm 3.26^{\mathrm{a}, \mathrm{b}}$ \\
Heart rate (beats/min) & $197.30 \pm 4.78$ & $166.0 \pm 16.20^{\mathrm{a}}$ & $191.0 \pm 7.81^{\mathrm{b}}$ \\
$\mathrm{Mean} \mathrm{ABP}(\mathrm{mmHg})$ & $92.61 \pm 3.88$ & $143.2 \pm 6.56^{\mathrm{a}}$ & $126.18 \pm 12.99^{\mathrm{a}, \mathrm{b}}$ \\
$\mathrm{Hb}(\mathrm{g} / \mathrm{dl})$ & $12.05 \pm 0.34$ & $7.33 \pm 0.65^{\mathrm{a}}$ & $8.02 \pm 0.46^{\mathrm{a}, \mathrm{b}}$ \\
\hline
\end{tabular}

Values are expressed as mean \pm SD. $p<0.05$ was considered significant. ${ }^{a} p<0.0001 v s$. Control group, ${ }^{\mathrm{b}} p<0.0001 v s$. Adenine group (One-way ANOVA followed by Tukey's post hoc test for multiple comparison).

A
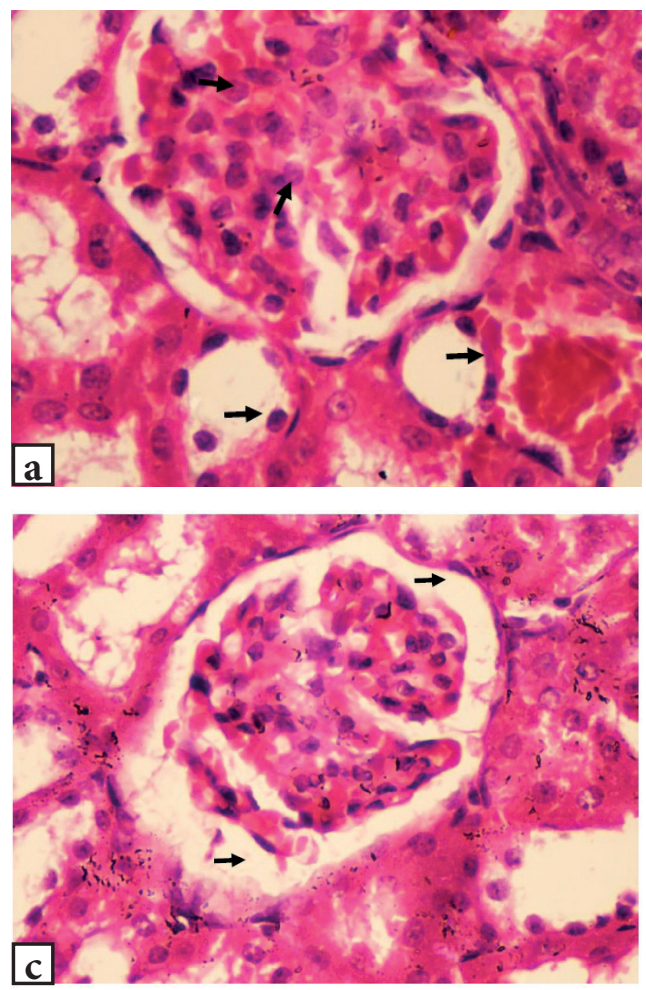
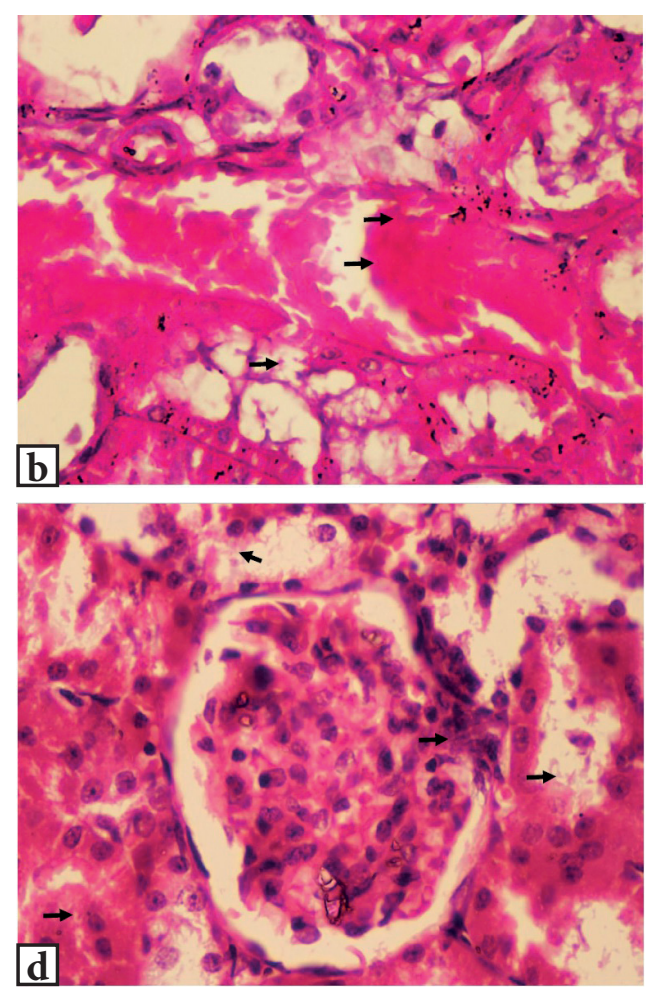

B

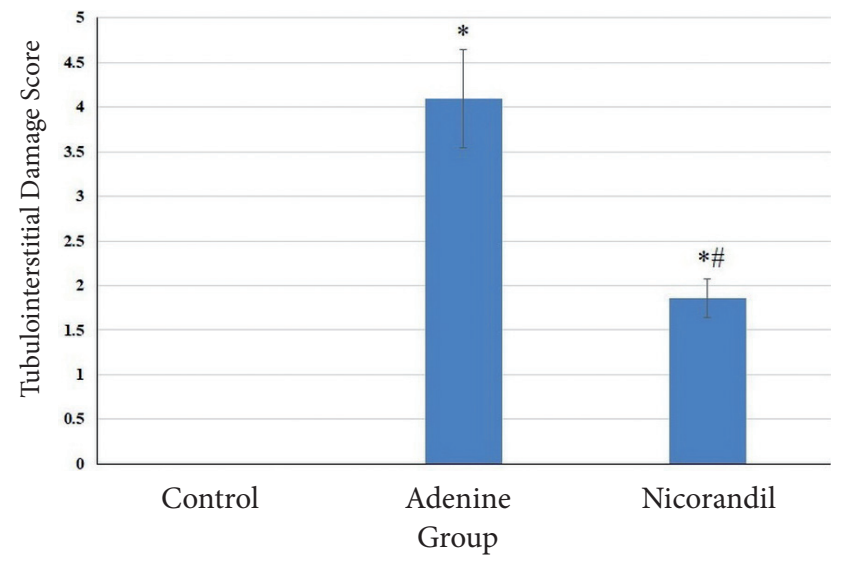

Figure 2. A. Photomicrographs of kidney specimens (H\&E, $\times 400)$. a. Control group. Normal glomerular structure and intact proximal tubular epithelium with normal brush border. b. and c. Adenine group. Arrow shows interstitial haemorrhage (b) and collapse of renal glomeruli and glomerulosclerosis (c). d. Nicorandil group. Hydropic degeneration in proximal tubules. B. Effect nicorandil on tubulointerstitial damage score. One-way ANOVA followed by Tukey's post hoc test for multiple comparison. ${ }^{*}$ significant $v$. Control group, ${ }^{\#}$ significant vs. Adenine group. 
protein excretion with significant decrease in serum $\mathrm{Ca}^{2+}$ in the Adenine group when compared to Control group $(p<$ 0.05). Concomitant administration of nicorandil ameliorated theses effect by causing a significant decrease in serum creatinine, serum $\mathrm{Na}^{+}, \mathrm{K}^{+}$and $\mathrm{PO}_{4}^{-}$, PRA and urinary protein excretion and a significant increase in serum $\mathrm{Ca}^{2+}$ compared to Adenine group $(p<0.001)$ (Table 3$)$.

\section{Effects of nicorandil on kidney morphology}

Kidney specimens from Adenine group showed significant increase in the glomerular and tubulointerstitial damage score compared to Control group $(p<0.001)$. Moreover, the degree of renal damage was significantly improved in Nicorandil group compared to Adenine group $(p<0.001)$ (Fig. 2B). Kidneys obtained from Adenine group showed irregular dilated renal tubules with dilated peritubular capillaries and glomerular expansion, and collapse and rarefaction (Fig. 2Aa-Ac), while kidneys obtained from Nicorandil group showing mild tubular injury in the form of few apoptotic cells and regeneration in the form of irregular dilated tubules and solid tubules and mesangial proliferation (Fig. 2Ad).

\section{Effects of nicorandil on structure of aorta and vascular} calcification in aortic tissues

H\&E staining showed normal structure of aorta in normal rats, while adenine-treated rats showed disorganized aortic endothelium and loss of elastic tissues. Treatment with nicorandil restored the intact endothelium and maintained the wavy collagen fibers (Fig. 3a-f). In Adenine group showed marked increase in VC in aorta by Von Kossa compared to Control group. Concomitant administration of nicorandil significantly decreased these calcifications compared to Adenine group (Fig. 4a-f).
Effects of nicorandil on expression of eNOS and nrf2 genes in aortic tissues

Adenine group showed significant decrease in expression of eNOS and $n r f 2$ genes in aortic tissues by real time PCR compared to Control group $(p<0.001)$. Concomitant administration of nicorandil with adenine significantly increased the expression of both eNOS and $n r f 2$ genes compared to Adenine group ( $p<0.001)$ (Fig. 5).

\section{Discussion}

In the present study, we found that administration of high adenine diet for 4 weeks caused significant deteriorations of the kidney functions and morphology, which was associated with elevated blood pressure, PRA and aortic VC with reduction in expression of $n r f 2$ and eNOS genes in aortic tissues. On the other hand, administration of nicorandil (vasodilator and $\mathrm{K}_{\mathrm{ATP}}$ channel opener) resulted in significant improvement in the vascular and renal disturbances induced by adenine.

In the present study, we used a well-established animal model of chronic nephropathy. The mechanisms underlying the pathophysiology of adenine-induced nephropathy include precipitation of dihydroxyadenine in renal tubules causing tubular cell injury and apoptosis, interstitial inflammatory cell infiltration and tubulointerstitial fibrosis resulting in progressive deterioration of kidney functions and CKD (Tamura et al. 2009; Tanaka et al. 2009). In agreement with previous studies, we found that high adenine intake $(0.75 \%$ w/w) for 4 weeks caused significant reduction in the body mass and $\mathrm{Hb}$ contents of rats (Nguy et al. 2012; Ali et al. 2014, 2015; Inami et al. 2014; Hussein et al. 2016) suggesting impairment of RBCs formation due to impairment of kidney functions and deficiency of erythropoietin secretion. In line

Table 3. Effects of treatment with nicorandil on serum creatinine, serum electrolytes $\left(\mathrm{PO}_{4}, \mathrm{~K}^{+}, \mathrm{Na}^{+}, \mathrm{Ca}^{2+}\right)$, urinary protein excretion and plasma renin activity

\begin{tabular}{|c|c|c|c|}
\hline & $\begin{array}{l}\text { Control group } \\
\quad(n=10)\end{array}$ & $\begin{array}{l}\text { Adenine group } \\
\quad(n=8)\end{array}$ & $\begin{array}{l}\text { Nicorandil group } \\
\qquad(n=10)\end{array}$ \\
\hline Serum creatinine $(\mathrm{mg} / \mathrm{dl})$ & $0.79 \pm 0.03$ & $1.87 \pm 0.27^{\mathrm{a}}$ & $1.05 \pm 0.08^{\mathrm{a}, \mathrm{b}}$ \\
\hline Serum $\mathrm{Ca}^{2+}(\mathrm{mg} / \mathrm{dl})$ & $7.68 \pm 0.44$ & $5.93 \pm 0.50^{\mathrm{a}}$ & $7.25 \pm 0.33^{\mathrm{b}}$ \\
\hline Serum $\mathrm{PO}_{4}(\mathrm{mg} / \mathrm{dl})$ & $5.14 \pm 0.14$ & $18.16 \pm 0.75^{\mathrm{a}}$ & $9.39 \pm 0.57^{\mathrm{a}, \mathrm{b}}$ \\
\hline Serum $\mathrm{Na}^{+}(\mathrm{mEq} / \mathrm{l})$ & $136.53 \pm 5.33$ & $169.8 \pm 5.20^{\mathrm{a}}$ & $148.36 \pm 5.64^{\mathrm{a}, \mathrm{b}}$ \\
\hline Serum $\mathrm{K}^{+}(\mathrm{mEq} / \mathrm{l})$ & $4.22 \pm 0.59$ & $6.26 \pm 0.58^{\mathrm{a}}$ & $5.03 \pm 0.18^{\mathrm{a}, \mathrm{b}}$ \\
\hline Urinary protein excretion (g/24 h urine) & $0.13 \pm 0.02$ & $1.41 \pm 0.26^{\mathrm{a}}$ & $0.21 \pm 0.02^{\mathrm{b}}$ \\
\hline Plasma renin activity (AngI/ml/h) & $0.22 \pm 0.03$ & $5.5 \pm 0.48^{\mathrm{a}}$ & $4.12 \pm 0.32^{\mathrm{a}, \mathrm{b}}$ \\
\hline
\end{tabular}

Values are expressed as mean \pm SD. $p<0.05$ was considered significant. ${ }^{\mathrm{a}} p<0.0001 v$ s. Control group, ${ }^{\mathrm{b}} p<0.0001 v$ s. Adenine group (One-way ANOVA followed by Tukey's post hoc test for multiple comparison). 
with this hypothesis, Rahman et al. (2018) demonstrated that administration of oral dose with adenine at $50 \mathrm{mg} / \mathrm{kg}$ for 28 days caused significant reduction in haematocrit value and plasma erythropoietin levels with significant increase in serum creatinine. On the other hand, coadministration of nicorandil with adenine prevented the reduction in body mass and $\mathrm{Hb}$ concentrations. However, the elevation in $\mathrm{Hb}$ contents in Nicorandil group was minimal and not reversed completely the drop in $\mathrm{Hb}$ contents to the normal level sug- gesting the effect of nicorandil on erythropoietin secretion is partial not complete.

Also, in agreement with previous studies, we found that high adenine intake caused marked elevation of mean arterial blood pressure (ABP) and PRA with significant reduction in HR (Kim et al. 2013; Zhao et al. 2014; Hussein et al. 2016). The significant increase in PRA suggests involvement of renin angiotensin system (RAS) in elevation of ABP. In addition, the significant reduction in HR suggests intact ba-
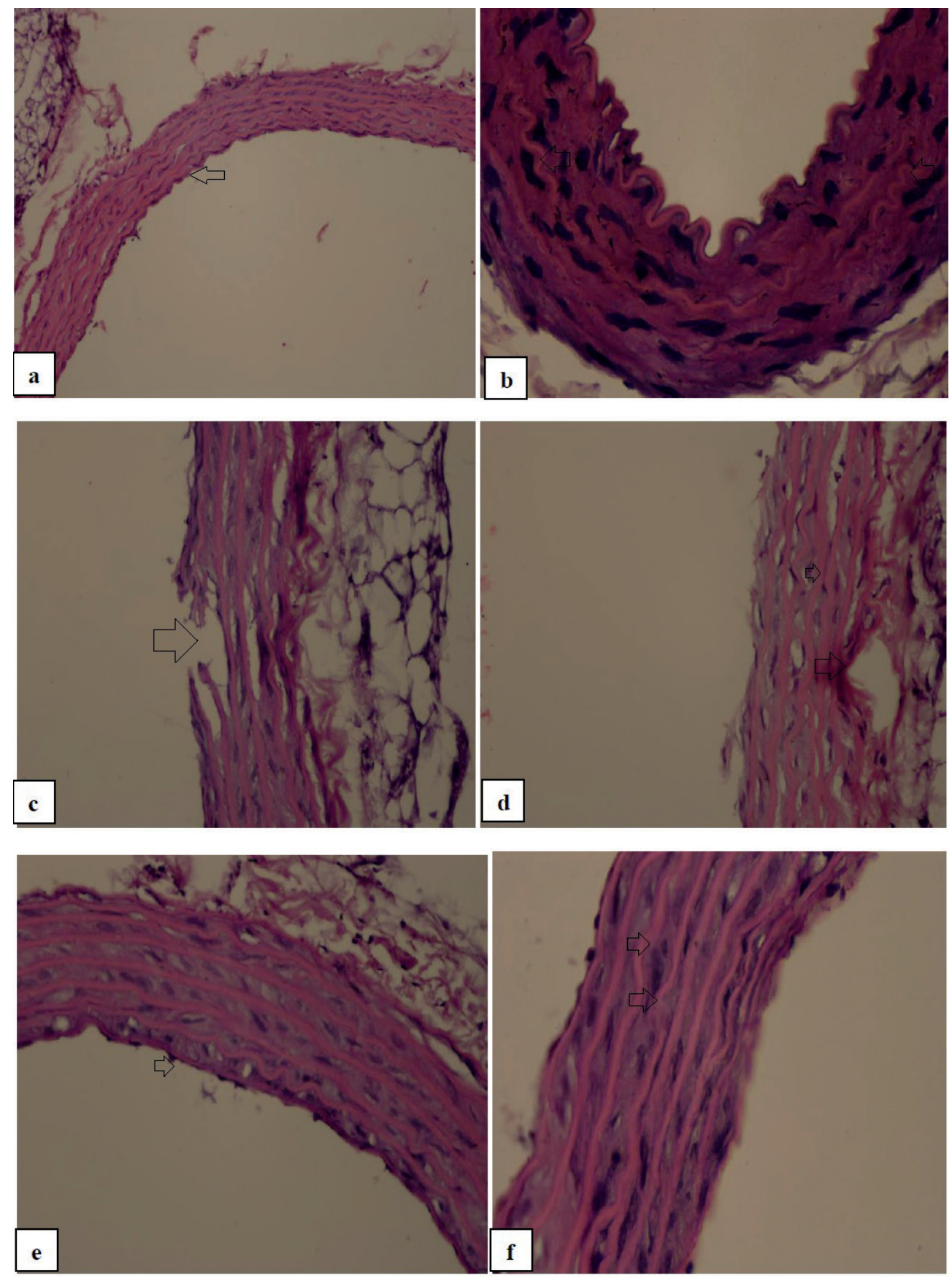

Figure 3. Specimen of aortic tissues showing intact aortic endothelium (a) and wavy collagen fibers (b) in Control group, disrupted aortic endothelium (c) with loss wavy collagen fibers (d) in Adenine group and intact endothelium of aorta (e) and wavy collagen fibers (f) in Nicorandil group. H\&E, $\times 200$ (a), $\times 400(\mathrm{~b}-\mathrm{f})$ 
roreceptor reflex in rats with adenine-induced-nephropathy. However, a study by Nguy and his colleagues (2012) demonstrated in a rat model of adenine-induced nephropathy, significant reduction in PRA and HR in adenine-treated rats, suggesting no role for RAS in adenine-induced nephropathy and impairment of baroreceptor reflex in adenine-induced nephropathy. This discrepancy in results might be due to the duration of adenine intake. In our study, adenine was given for 4 weeks and in Nguy et al. (2012) study, adenine was given for a longer time (11 weeks). On other hand, pretreatment with nicorandil in adenine-treated rats caused significant improvement in $\mathrm{ABP}$ and $\mathrm{HR}$ with minimal reduction in
PRA. The dose of nicorandil in the present study was chosen because it was not associated with any change in the blood pressure or serum aldosterone or PRA (Sudo et al. 2008).

Regarding the renal effects of adenine on kidney functions and morphology, the present study showed significant increase in serum creatinine and urinary protein excretion in Adenine group suggesting impairment of glomerular and tubular kidney functions. Moreover, the histopathological examination showed significant damage in the renal tubules, glomerulosclerosis and interstitial inflammatory cells and fibrosis. These findings are in agreement with those reported by previous studies (Aminzadeh et al. 2013; Kim et al. 2013;

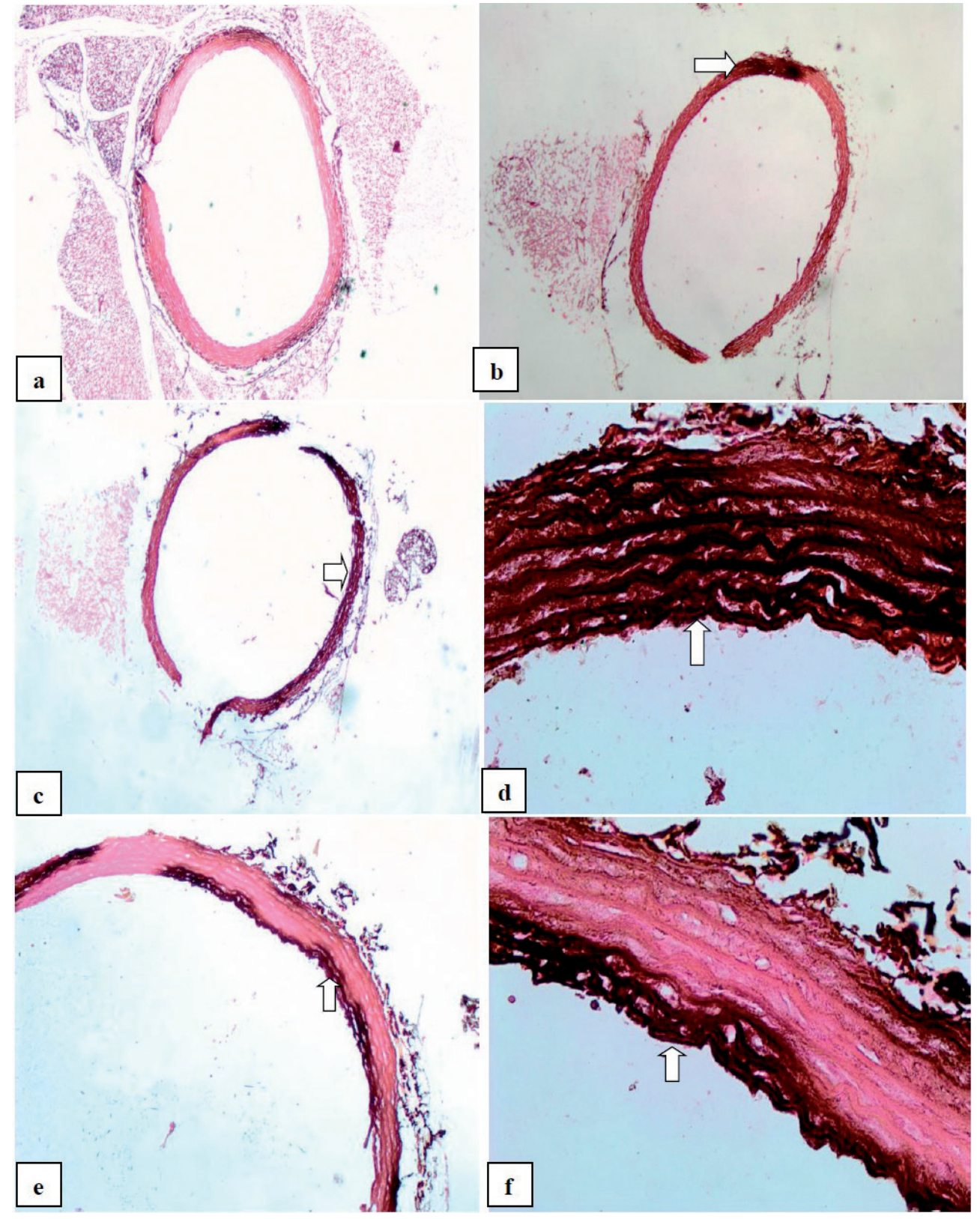

Figure 4. Specimen of aortic tissues showing no vascular calcifications by von Kossa stain in Control group (a), marked aortic vascular calcifications in Adenine group in patches (b), half of the aorta (c) and with high power (d) and minimal calcifications in Nicorandil group $(e, f) . \times 40(a, b, c, e)$, $\times 400$ (d), $\times 200$ (f). 

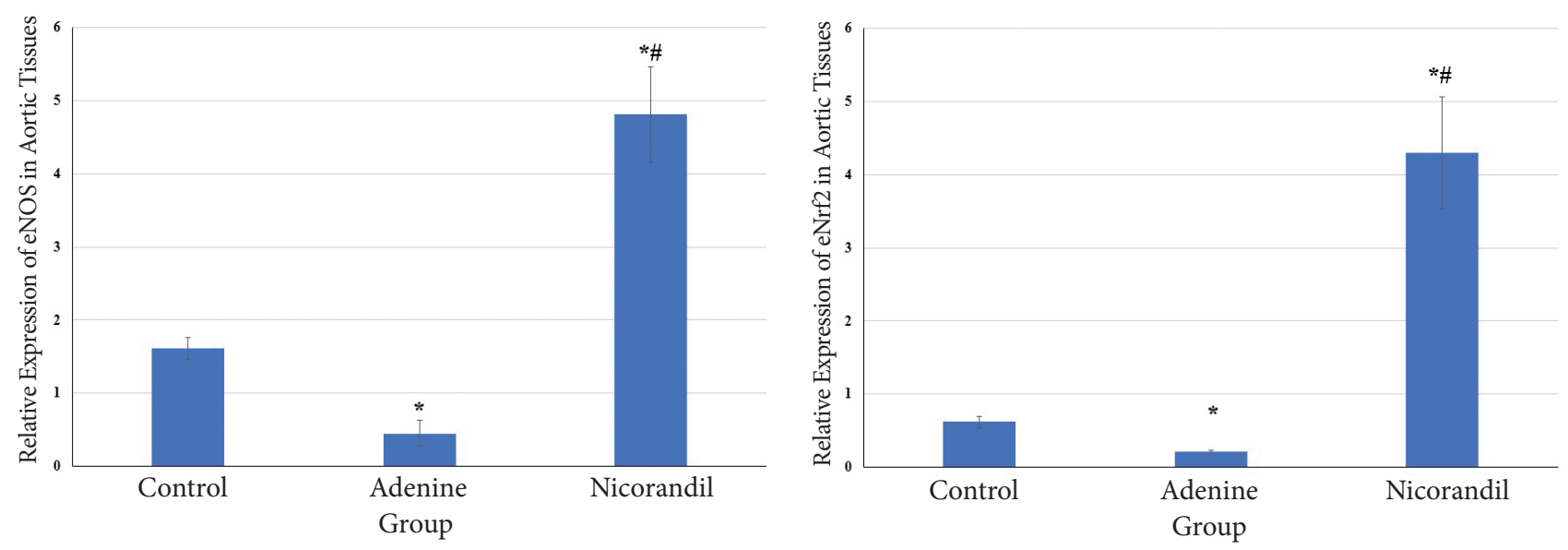

Figure 5. Relative expression of mRNA of eNOS (A) and Nrf2 (B) in aortic tissues in different groups. One-way ANOVA followed by Tukey's post hoc test for multiple comparison.* significant $v s$. Control group, ${ }^{\#}$ significant $v s$. Adenine group.

Ali et al. 2014; Hussein et al. 2016). Moreover, we found in the present study normalization of the kidney functions and morphology by co-administration of nicorandil with adenine suggesting renoprotective role for nicorandil against adenine-induced nephropathy. This renoprotective effect for nicorandil was shown in rat models of renal I/R injury (Shimizu et al. 2011) and partial unilateral ureteral obstruction (Ozturk et al. 2017). In addition, Tamura et al. (2012) demonstrated the renoprotective effects of nicorandil on a rat remnant kidney model of chronic kidney disease. Moreover, Shiraishi et al. (2014) demonstrated that nicorandil might synergize with renoprotective effects of enalapril in chronic kidney disease.

In the present study, we found aortic calcifications in Adenine group. These results are in line with previous studies (Subhash et al. 2015; Ravindran et al. 2017a, 2017b). VC are not passive process, but it is an active process, in which the vascular cells are transformed to osteoblast like cells. Calcium and phosphorous levels in blood and in tissues are the key players of VC seen in patients with chronic kidney disease (Patsalas et al. 2007). In the present study, we found electrolyte changes in the form of elevated serum $\mathrm{K}^{+}, \mathrm{Na}^{+}$ and $\mathrm{PO}_{4}$ with significant decrease in serum $\mathrm{Ca}^{2+}$ caused by adenine administration for 4 weeks. These electrolytes disturbances are in line with previous studies (Jia et al. 2013; Kim et al. 2013; Zhao et al. 2014; Hussein et al. 2016), and due to impairment of tubular functions by adenine administration (Ikeda et al. 2010; Kim et al. 2013). Hypernatremia shown in the present study could be explained by reduction in the filtered load of $\mathrm{Na}^{+}$due to reduction of glomerular filtration (GFR) and activation of renin angiotensin system, which enhance $\mathrm{Na}^{+}$retention. Also, we found in this work significant improvement in disturbed electrolyte imbalance induced by adenine via nicorandil administration suggesting renoprotective role for nicorandil; a mechanism by which nicorandil prevented VC.

Previous studies suggested a relation between mitochondrial oxidative stress and VC. Ravindran et al. (2017b) demonstrated that high adenine diet $(0.75 \%)$ for 4 weeks (28 days) caused significant elevation in the calcium, phosphorus product in the brain with enhanced oxidative stress in the cytoplasm and mitochondria of cerebral neurons (elevated TBARS and decline in the antioxidant enzymes) suggesting a relation between oxidative stress and VC. Mitochondrial dysfunction is the common pathological features in the diseases related to calcification (Ahn et al. 2010). Mitochondria play significant role in process of $\mathrm{VC}$ where insoluble calcium phosphate salts are deposited in the mitochondrial matrix (Millane et al. 1994). Oxidative stress activates several endogenous cytoprotective and cellular antioxidant proteins and enzymes that limit the degree of tissue injury and dysfunction. Nrf2 factor is a transcription factor that regulates the basal activity and the induction of numerous genes that encode various antioxidants and phase 2 detoxifying enzymes (Kobayashi et al. 2006; Wakabayashi et al. 2010). In the present study, we found reduction in the expression of $n r f 2$ in aortic tissues at the levels of mRNA by Adenine group suggesting the high adenine diet impaired the activity of $n r f 2$ in aortic tissues. Previous studies reported downregulation of $n r f 2$ in adenine-induced renal failure (Aminzadeh et al. 2013; Hussein et al. 2016).

Moreover, Subhash and others (2015) demonstrated a direct link between the arterial calcification in major arteries and vascular brain disease where common link is believed to be mitochondrial $\mathrm{K}_{\mathrm{ATP}}$ channel. The link between the ATP sensitive $\mathrm{K}_{\mathrm{ATP}}$ channel and ROS clarifies the intracellular mechanism of vascular calcification and may allow exploration of mitochondrial $\mathrm{K}_{\mathrm{ATP}}$ channel modulator and 
antioxidants as therapeutic agents for vascular calcification. In the present study, nicorandil ( $\mathrm{K}_{\mathrm{ATP}}$ channel opener) pretreatment caused upregulation of nrf2 in aortic tissues obtained from rats treated with high adenine diet at the level of mRNA suggesting improvement of oxidative stress in aortic tissues might reduce the aortic calcifications. The antioxidant action of nicorandil was demonstrated in a rat model of remnant kidney disease (Tamura et al. 2012; Shiraishi et al. 2014), rat model of renal I/R injury (Ozturk et al. 2017) and brain injury after cardiac arrest in pigs (Zhu et al. 2018).

Endothelial dysfunctions in chronic kidney disease was demonstrated in high adenine rat model and occurred in the form of imbalance between the vasodilators (serum nitric oxide) and vasoconstrictors (serum endothelin) (Peng et al 2013; Ali et al. 2015). In the present study, we found down-regulation of eNOS that enhanced the production of vasodilator (nitric oxide) in aortic tissues in adeninetreated group, indicating that adenine impaired the vasodilator responses of the vascular endothelium. Nicorandil pretreatment caused significant increase in the expression of eNOS in the aortic tissues of adenine-treated and normal rats, suggesting that upregulation of eNOS might be a potential protective mechanism for nicorandil against adenine-induced VC. To the best of our knowledge, this is the first study that examined the role of eNOS as a potential mechanism for the improvement of adenine with nicorandil. However, Date et al. (2005), Hongo et al. (2005) and Tashiro et al. (2015) showed that nicorandil increased endotheliumderived NO production by activation of eNOS, inhibited endothelial cell death, and exerted anti-inflammatory and antioxidative effects and this may contribute to the protective effect of nicorandil.

\section{Conclusions}

High adenine diet $(0.75 \% \mathrm{w} / \mathrm{w})$ for 4 weeks caused significant deteriorations of kidney functions and morphology, and aortic VC with downregulations of nrf2 and eNOS. Nicorandil ( $K_{\text {ATP }}$ channel opener) ameliorated the vascular and renal harmful effects of adenine, which might be due to improvement of the renal glomerular and tubular functions, correction of electrolyte imbalance and upregulation of $n r f 2$ and $e N O S$ in aortic tissues.

Conflict of interest. Authors declared that there was no conflict of interest

\section{References}

Ahn SY, Choi YS, Koo HJ, Jeong JH, Park WH, Kim M, Piao Y, Pak YK (2010): Mitochondrial dysfunction enhances the migration of vascular smooth muscles cells via suppression of Akt phosphorylation. Biochim. Biophys. Acta 1800, 275-281

https://doi.org/10.1016/j.bbagen.2009.09.005

Ali BH, Adham SA, Al Za'abi, Waly M, Yasin J, Nemmar A, Schupp N (2015): Ameliorative effect of chrysin on adenineinduced chronic kidney disease in rats. PLoS One, 10, e0125285 https://doi.org/10.1371/journal.pone.0125285

Ali BH, Alzáabi M, Ramkumar A, Al-Lawati I, Waly MI, Beegam S, Nemmar A, Brand S, Schupp N (2014): The effect of activated charcoal on adenine-induced chronic renal failure in rats. Food Chem. Toxicol. 65, 321-328 https://doi.org/10.1016/j.fct.2013.12.038

Aminzadeh MA, Nicholas SB, Norris KC, Vaziri ND (2013): Role of impaired Nrf2 activation in the pathogenesis of oxidative stress and inflammation in chronic tubulo-interstitial nephropathy. Nephrol. Dial. Transplant. 28, 2038-2045 https://doi.org/10.1093/ndt/gft022

Askari H, Seifi B, Kadkhodaee M (2016): Evaluation of renalhepatic functional indices and blood pressure based on the progress of time in a rat model of chronic kidney disease. Nephrourol. Mon. 8, e37840

https://doi.org/10.5812/numonthly. 37840

Barbato JC (2005): Nicorandil: the drug that keeps on giving. Hypertension 46, 647-648

https://doi.org/10.1161/01.HYP.0000185191.86908.a7

Chang YK, Hsu CC, Chen PC, Chen YS, Hwang SJ, Li TC, Huang CC, Li CY, Sung FC (2015): Trends of cost and mortality of patients on haemodialysis with end stage renal disease. Nephrology 20, 243-249

https://doi.org/10.1111/nep.12380

Chang XY, Cui L, Wang XZ, Zhang L, Zhu D, Zhou XR, Hao LR (2017): Quercetin attenuates vascular calcification through suppressed oxidative stress in adenine-induced chronic renal failure rats. BioMed. Int. 2017, 5716204 https://doi.org/10.1155/2017/5716204

Date T, Taniguchi I, Inada K, Matsuo S, Miyanaga S, Yamane T, Abe Y, Sugimoto K, Mochizuki S (2005): Nicorandil inhibits serum starvation-induced apoptosis in vascular endothelial cells. J. Cardiovasc. Pharmacol. 46, 721-726

https://doi.org/10.1097/01.fjc.0000184466.37951.76

Diwan V, Brown L, Gobe GC (2018): Adenine-induced chronic kidney disease in rats. Nephrology 23, 5-11

https://doi.org/10.1111/nep.13180

Franczyk-Skóra B, Gluba A, Banach M, Rozentryt P, Poloński L, Rysz J (2013): Acute coronary syndromes in patients with chronic kidney disease. Curr. Vasc. Pharmacol. 11, 758-767 https://doi.org/10.2174/1570161111311050013

Hongo M, Mawatari E, Sakai A, Ruan Z, Koizumi T, Terasawa F, Yazaki Y, Kinoshita O, Ikeda U, Shibamoto T (2005): Effects of nicorandil on monocrotaline-induced pulmonary arterial hypertension in rats. J. Cardiovasc. Pharmacol. 46, 452-458 https://doi.org/10.1097/01.fjc.0000176728.74690.09

Hussein AM, Malek AA, Saad MA (2016): Renoprotective effects of aliskiren on adenine-induced tubulointerstitial nephropathy: possible underlying mechanisms. Can. J. Physiol. Pharmacol. 94, 829-837 https://doi.org/10.1139/cjpp-2015-0364 
Ikeda R, Imai Y, Maruyama W, Mizoguchi K (2010): Systemic disorders of calcium dynamics in rats with adenine-induced renal failure: Implication for chronic kidney disease-related complications. Nephrology 15, 54-62 https://doi.org/10.1111/j.1440-1797.2009.01161.x

Inami Y, Hamada C, Seto T, Hotta Y, Aruga S, Inuma J, Azuma K, Io H, Kaneko K, Watada H, et al. (2014): Effect of AST-120 on endothelial dysfunction in adenine-induced uremic rats. Int. J. Nephrol. 2014, 164125 https://doi.org/10.1155/2014/164125

Ishii H, Toriyama T, Aoyama T, Takahashi H, Yamada S, Kasuga H, Ichimiya S, Kanashiro M, Mitsuhashi H, Maruyama S, et al. (2007): Efficacy of oral nicorandil in patients with endstage renal disease: a retrospective chart review after coronary angioplasty in Japanese patients receiving hemodialysis. Clin. Ther. 29, 110-122 https://doi.org/10.1016/j.clinthera.2007.12.020

Jia T, Olauson H, Lindberg K, Amin R, Edvardsson K, Lindholm B, Andersson G, Wernerson A, Sabbagh Y, Schiavi S, et al. (2013). A novel model of adenine-induced tubulointerstitial nephropathy in mice. BMC Nephrology 14, 116 https://doi.org/10.1186/1471-2369-14-116

Kim EJ, Oh HA, Choi HJ, Park JH, Kim DH, Kim NJ (2013): Heat processed ginseng saponin ameliorates the adenine-induced renal failure in rats. J. Ginseng Res. 37, 87-93 https://doi.org/10.5142/jgr.2013.37.87

Kobayashi A, Kang MI, Watai Y, Tong KI, Shibata T, Uchida K, Yamamoto M (2006): Oxidative and electrophilic stresses activate Nrf2 through inhibition of ubiquitination activity of Keap1. Mol. Cell Biol. 26, 221-229 https://doi.org/10.1128/MCB.26.1.221-229.2006

Lavi-Moshayoff V, Wasserman G, Meir T, Silver J, Naveh-Many T (2010): PTH increases FGF23 gene expression and mediates the high-FGF23 levels of experimental kidney failure: a bone parathyroid feedback loop. Am. J. Physiol. Renal Physiol. 299, F882-889 https://doi.org/10.1152/ajprenal.00360.2010

Levey AS, Atkins R., Coresh J, Cohen EP, Collins AJ, Eckardt K-U, Nahas ME, Jaber BL, Jadoul M, Levin A, et al. (2007): Chronic kidney disease as a global public health problem: approaches and initiatives: a position statement from Kidney Disease Improving Global Outcomes. Kidney Int. 72, 247-259 https://doi.org/10.1038/sj.ki.5002343

Levin A (2003): Clinical epidemiology of cardiovascular disease in chronic kidney disease prior to dialysis. Semin. Dial. 16, 101-105 https://doi.org/10.1046/j.1525-139X.2003.16025.x

Livak KJ, Schmittgen TD (2001): Analysis of relative gene expression data using real-time quantitative PCR and the 2(-DDC (t)). Methods 25, 402-408 https://doi.org/10.1006/meth.2001.1262

Lopez-Novoa JM, Rodriguez-Pena AB, Ortiz A, Martinez-Salgado C, Lopez Hernandez FJ (2011): Etiopathology of chronic tubular, glomerular and renovascular nephropathies: Clinical implications. J. Transl. Med. 9, 13 https://doi.org/10.1186/1479-5876-9-13

Millane T, Wilson AJ, Patel MK, Jennison SH, Holt DW, Murday AJ, Camm AJ (1994): Mitochondrial calcium deposition in association with cyclosporine therapy and myocardial mag- nesium depletion: a serial histologic study in heart transplant recipients. J. Heart Lung Transplant. 13, 473-480

Nguy L, Nilsson H, Lundgren J, Johansson ME, Teerlink T, Scheffer PG, Guron G (2012): Vascular function in rats with adenineinduced chronic renal failure. Am. J. Physiol. Regul. Integr. Comp. Physiol. 302, R1426-1435 https://doi.org/10.1152/ajpregu.00696.2011

Nicholas SB, Yuan J, Aminzadeh A, Norris KC, Crum A, Vaziri ND (2012): Salutary effects of a novel oxidative stress modulator on adenine induced chronic progressive tubulointerstitial nephropathy. Am. J. Transl. Res. 4, 257-268

Oh J, Wunsch R, Turzer M, Bahner M, Raggi P, Querfeld U, Mehls O, Schaefer F (2002): Advanced coronary and carotid arteriopathy in young adults with childhood-onset chronic renal failure. Circulation 106, 100-105 https://doi.org/10.1161/01.CIR.0000020222.63035.C0

Ozturk H, Firat T, Tekce BK, Yilmaz F, Ozturk H (2017): Effects of nicorandil on renal function and histopathology in rats with partial unilateral ureteral obstruction. Kaohsiung J. Med. Sci. 33, 236-245 https://doi.org/10.1016/j.kjms.2017.03.003

Patsalas S, Eleftheriadis T, Spaia S, Theodoroglou H, Antoniadi G, Liakopoulos V, Passadakis P, Vayonas G, Vargemezis V (2007): Thirty month follow up of coronary artery calcification in hemodialysis patients: different roles for inflammation and abnormal calcium phosphorous metabolism? Ren. Fail. 29, 623-629 https://doi.org/10.1080/08860220701395010

Peng M, Cai P, Ma H, Meng H, Xu Y, Zhang X, et al. (2013): Chinese herbal medicine Shenqi Detoxification Granule inhibits fibrosis in adenine induced chronic renal failure rats. Afr. J. Tradit. Complement Altern. Med. 11, 194-204 https://doi.org/10.4314/ajtcam.v11i1.31

Porter CJ, Stavroulopoulos A, Roe SD, Pointon K, Cassidy MJ (2007): Detection of coronary and peripheral artery calcification in patients with chronic kidney disease stages 3 and 4, with and without diabetes. Nephrol. Dial. Transplant. 22, 3208-3213 https://doi.org/10.1093/ndt/gfm377

Rahman A, Yamazaki D, Sufiun A, Kitada K, Hitomi H, Nakano D, Nishiyama A (2018): A novel approach to adenine-induced chronic kidney disease associated anemia in rodents. PLoS One 13, e0192531 https://doi.org/10.1371/journal.pone.0192531

Ravindran S, Murali J, Amirthalingam SK, Gopalakrishnan S, Kurian GA (2017a): Vascular calcification abrogates the nicorandil mediated cardioprotection in ischemia reperfusion injury of rat heart. Vascul. Pharmacol. 89, 31-38 https://doi.org/10.1016/j.vph.2016.12.004

Ravindran S, Swaminathan K, Ramesh A, Kurian GA (2017b): Nicorandil attenuates neuronal mitochondrial dysfunction and oxidative stress associated with murine model of vascular calcification. Acta Neurobiol. Exp. 77, 57-67 https://doi.org/10.21307/ane-2017-036

Sarnak MJ, Levey AS, Schoolwerth AC, Coresh J, Culleton B, Hamm LL, McCullough PA, Kasiske BL, Kelepouris E, Klag MJ, et al. (2003): Kidney disease as a risk factor for development of cardiovascular disease: a statement from the American Heart 
Association Councils on kidney in cardiovascular disease, high blood pressure research, clinical cardiology, and epidemiology and prevention. Circulation 108, 2154-2169 https://doi.org/10.1161/01.CIR.0000095676.90936.80

Shimizu S, Saito M, Kinoshita Y, Ohmasa F, Dimitriadis F, Shomori K, Hayashi A, Satoh K. (2011): Nicorandil ameliorates ischaemia-reperfusion injury in the rat kidney. Br. J. Pharmacol. 163, 272-282 https://doi.org/10.1111/j.1476-5381.2011.01231.x

Shiraishi T, Tamura Y, Taniguchi K, Higaki M, Ueda S, Shima T, Nagura M, Nakagawa T, Johnson RJ, Uchida S (2014): Combination of ACE inhibitor with nicorandil provides further protection in chronic kidney disease. Am. J. Physiol. Renal Physiol. 307, F1313-1322 https://doi.org/10.1152/ajprenal.00521.2014

Sigrist MK, Taal MW, Bungay P, McIntyre CW (2007): Progressive vascular calcification over 2 years is associated with arterial stiffening and increased mortality in patients with stages 4 and 5 chronic kidney disease. Clin. J. Am. Soc. Nephrol. 2, 1241-1248 https://doi.org/10.2215/CJN.02190507

Soetikno V, Sari FR, Lakshmanan AP, Arumugam S, Harima M, Suzuki K, Kawachi H, Watanabe K (2013): Curcumin alleviates oxidative stress, inflammation, and renal fibrosis in remnant kidney through the Nrf2-keap1 pathway. Mol. Nutr. Food Res. 57, 1649-1659 https://doi.org/10.1002/mnfr.201200540

Subhash N, Sriram R, Kurian GA (2015) Sodium thiosulfate protects brain in rat model of adenine induced vascular calcification. Neurochem. Int. 90, 193-203 https://doi.org/10.1016/j.neuint.2015.09.004

Sudo H, Yogo K, Ishizuka N, Otsuka H, Horie S, Saito K. (2008): Nicorandil, a potassium channel opener and nitric oxide donor, improves the frequent urination without changing the blood pressure in rats with partial bladder outlet obstruction. Biol. Pharm. Bull. 31, 2079-2082 https://doi.org/10.1248/bpb.31.2079

Tamura Y, Tanabe K, Kitagawa W, Uchida S, Schreiner GF, Johnson RJ, Nakagawa T (2012): Nicorandil, a Katp channel opener, alleviates chronic renal injury by targeting podocytes and macrophages. Am. J. Physiol. Renal Physiol. 303, F339-349 https://doi.org/10.1152/ajprenal.00158.2012
Tanaka T, Doi K, Maeda-Mamiya R, Negishi K, Portilla D, Sugaya T, Fujita T, Noiri E (2009): Urinary L-type fatty acid-binding protein can reflect renal tubulointerstitial injury. Am. J. Pathol. 174, 1203-1211 https://doi.org/10.2353/ajpath.2009.080511

Tashiro Y, Yogo K, Serizawa K, Endo K (2015): Nicorandil suppresses urinary protein excretion and activates eNOS in Dahl salt sensitive hypertensive rats. Clin. Exp. Nephrol. 19, 343-349 https://doi.org/10.1007/s10157-014-0998-6

Trujillo J, Chirino YI, Molina-Jijon E, Anderica-Romero AC, Tapia E, Pedraza-Chaverri J (2013): Renoprotective effect of the antioxidant curcumin: recent findings. Redox Biol. 1, 448-456 https://doi.org/10.1016/j.redox.2013.09.003

Vomund S, Schäfer A, Parnham MJ, Brüne B, von Knethen A (2017): Nrf2, the master regulator of anti-oxidative responses. Int. J. Mol. Sci. 18, 2772 https://doi.org/10.3390/ijms18122772

Wakabayashi N, Slocum SL, Skoko JJ, Shin S, Kensler TW (2010): When NRF2 talks, whos listening? Antioxid. Redox Signal. 13, $1649-1663$ https://doi.org/10.1089/ars.2010.3216

Yamada S, Taniguchi M, Tokumoto M, Toyonaga J, Fujisaki K, Suehiro T, Noguchi H, Iida M, Tsuruya K, Kitazono T (2012): The antioxidant tempol ameliorates arterial medial calcification in uremic rats: important role of oxidative stress in the pathogenesis of vascular calcification in chronic kidney disease. J. Bone Miner Res. 27, 474-485 https://doi.org/10.1002/jbmr.539

Zhao Y-Y, Chen H, Tian T, Chen D-Q, Bai X, Wei F (2014): A pharmaco-metabonomic study on chronic kidney disease and therapeutic effect of ergone by UPLC-QTOF/HDMS. PLoS One, 9, e115467 https://doi.org/10.1371/journal.pone.0115467

Zhu F, Zhong X, Zhou Y, Hou Z, Hu H, Liang L, Chen J, Chen Q, Ji X, Shang D (2018): Protective effects of nicorandil against cerebral injury in a swine cardiac arrest model. Exp. Ther. Med. 16, 37-44

https://doi.org/10.3892/etm.2018.6136

Received: April 29, 2019

Final version accepted: August 8, 2019

First published online: October 7, 2019 